\title{
PENGEMBANGAN PERANGKAT PEMBELAJARAN DENGAN METODE PEMBELAJARAN PENEMUAN TERBIMBING (GUIDED DISCOVERY LEARNING) UNTUK MELATIH KETERAMPILAN BERPIKIR KRITIS DAN PENGUASAAN KONSEP PADA SISWA SMP
}

\author{
Rahmawati ${ }^{1)}$ \\ Wahono Widodo ${ }^{2)}$ \\ Prabowo ${ }^{2)}$
}

1) Mahasiswa Prodi Pendidikan Sains Program Pascasarjana Unesa

2) Dosen Prodi Pendidikan Sains Program Pascasarjana Unesa

\begin{abstract}
This research focuses to produce learning material of science lesson for Junior High School at the eighth grade in the topic of mirror using guided discovery learning method. This research consists of three steps with design one group pretest-posttest. Analyze data by using descriptive analyze N-Gain, T-Test, and ANOVAs one way. The results of this research are learning material of lesson what have been developed, generally, in the good category. Implementation of lesson plan is good. More student activities are making hypothesis, writing identification of variables and doing experiment to each group are 9.9\%, 9.8\%, and 9.8\%. The result of research showed that average $N$-Gains for each indicator of critical thinking skill are middle category. That is cleared of inferential analyzes $t$-Test what showed that there is significant differences between pretest and posttests on the result of critical thinking skill tests and tests of lesson, include of analyze by ANOVAs one way.. The other results are that based on analyzes of maximum criteria completeness (KKM), guided discovery learning method gives influence of result student cognitive test for three groups which is complete. The response of students to instruction with guided discovery learning method is good. Based on the result of research, conclusion of this research is the instruction of physics or science by using guided discovery learning can develop critical thinking skill and complete results of student cognitive lesson.
\end{abstract}

Key words: Critical thinking skill; guided discovery learning method

\begin{abstract}
Abstrak: Penelitian ini bertujuan untuk mengembangkan perangkat pembelajaran IPA fisika siswa SMP kelas VIII pada sub materi cermin dengan metode (guided discovery). Penelitian ini terdiri dari 3 tahap dengan rancangan menggunakan one group pretestposttest design. Analisis data dengan menggunakan analisis deskriptif N-Gain, T-Test, dan Anava Satu Jalur. Temuan dari hasil penelitian ini yaitu perangkat pembelajaran yang dikembangkan secara umum berkategori baik. Keterlaksanaan RPP berkategori baik. Aktivitas siswa yang dominan adalah membuat hipotesis, menuliskan identifikasi variabel-variabel percobaan dan melakukan percobaan untuk setiap kelompok berturut-turut adalah $9.9 \%, 9.8 \%$, dan 9.8\%. Hasil penelitian ini juga menunjukkan bahwa $N$ gain rata-rata keterampilan berpikir kritis berada pada kategori sedang. Temuan lain bahwa berdasarkan tinjauan KKM, metode pembelajaran penemuan terbimbing juga memberikan pengaruh pada penguasaan konsep siswa untuk ketiga kelompok berada pada kategori tuntas. Respon siswa terhadap pembelajaran dengan metode guided discovery dinilai baik. Berdasarkan hasil tersebut, disimpulkan bahwa pembelajaran IPA fisika dengan metode guided discovery dapat melatih keterampilan berpikir kritis siswa SMP serta mampu menuntaskan penguasaan konsep kognitif siswa.
\end{abstract}

Kata-kata kunci: Keterampilan berpikir kritis, metode penemuan terbimbing (guided discovery)

\section{Pendahuluan}

Salah satu proses berpikir tingkat tinggi adalah proses berpikir kritis. Ada beberapa alasan mengapa siswa dituntut agar terbiasa dalam melakukan proses berpikir kritis. Selain untuk memenuhi pencapaian tujuan pembelajaran IPA sebagaimana yang disebutkan pada tujuan ke empat dari standar isi, yaitu melakukan inkuiri ilmiah untuk menumbuhkan kemampuan berpikir, bersikap, dan bertindak ilmiah serta berkomunikasi, juga untuk memenuhi tuntutan SKL pada poin ke (2) yaitu menunjukkan kemampuan berpikir logis, kritis, kreatif, dan inovatif. Penjelasan ini diperkuat oleh pernyataan Wahab (dalam Maulana, 2008: 1) yaitu berpikir kritis merupakan aspek dalam memecahkan permasalahan secara kreatif agar peserta didik dapat bersaing secara adil dan mampu bekerja sama dengan bangsa lain.

Nurmaliah (2009) menyatakan di sekolah menengah pertama merupakan saat yang tepat untuk awal mengajarkan keterampilan tingkat tinggi atau proses berpikir kompleks, karena perkembangan kapasitas kognitif siswa remaja telah matang untuk diberikan tantangan berupa berpikir lebih kompleks. Menurut Piage, perkembangan kemampuan berpikir termasuk penalaran pada anak adalah usia 7-11 tahun mampu mengembangkan kemampuan berpikir konkrit (taraf operasional konkrit), dan pada usia 11-15 tahun sudah mampu mengembangkan pemikiran abstrak dan penalaran logis untuk berbagai macam persoalan (tahap operasional formal) (Hergenhahn, 2008). 
Untuk dapat mengukur kemampuan berpikir kritis siswa, maka seorang guru harus mengetahui indikator seorang siswa dikatakan berpikir kritis. Dressel \& Mayhew (1954, dalam Morgan, 1995) mengutip indikator-indikator tentang berpikir kritis yang dikembangkan oleh Komite Berpikir Kritis (Intercollege Committee on Critical Thinking) yaitu meliputi: 1) merumuskan masalah dan hipotesis, 2) menyeleksi informasi dan data untuk menyelesaikan masalah, 3) mengenali asumsi-asumsi, dan 4) menarik kesimpulan dan mengambil tindakan. Sedangkan menurut Ennis (1985, dalam Nurmaliah, 2009) indikator kemampuan berpikir kritis adalah merumuskan masalah, memberikan argumentasi, melakukan deduksi, melakukan induksi, melakukan evaluasi, dan mampu dalam pengambilan keputusan. Dari sejumlah indikator berpikir kritis di atas, maka dalam penelitian ini ditetapkan 5 indikator berpikir kritis yaitu merumuskan masalah, memberikan argumentasi, melakukan analisis, melakukan evaluasi, dan memutuskan.

Mengajarkan untuk mampu melatihkan keterampilan berpikir dengan cara eksplisit kemudian dipadukan ke dalam materi pembelajaran IPA dapat membantu para siswa untuk menjadi pemikir yang kritis secara efektif yang pada akhirnya bermuara pada ketuntasan penguasaan konsep siswa (Nurmaliah, 2009). Selanjutnya, kenyataan yang dijumpai di lapangan bahwa hanya sebagain kecil guru-guru di beberapa sekolah SMP dan sederajat di Indonesia, utamanya guru-guru yang memegang bidang mata pelajaran IPA, membiasakan untuk mengembangkan keterampilan berpikir kritis siswa yang pada akhirnya mempengaruhi penguasaan konsep IPA siswa yang bermuara pada peningkatan sumber daya manusia Indonesia (Jalal, 2012: 2).

Pernyataan ini diperkuat oleh hasil diskusi terbuka antara pihak sekolah SMP YDWP Lab. Unesa yaitu beberapa guru bidang studi IPA dengan peneliti bahwa ada beberapa alasan yang menyebabkan hal tersebut belum terlaksana diantaranya: (1) guru-guru bidang studi IPA belum banyak mengetahui model-model pembelajaran inovatif serta kesulitan mencari strategi yang tepat agar siswa dengan kemampuan yang rendah dapat aktif belajar, dengan fasilitas dan sumber belajar yang terbatas, (2) tingkat kemampuan guru-guru mata pelajaran IPA belum banyak dalam mengembangkan perangkat pembelajaran yang mampu melatih keterampilan berpikir kritis siswa dan (3) keterbatasan waktu guru-guru mata pelajaran IPA untuk dapat menyediakan perangkat pembelajaran dalam melatih keterampilan berpikir kritis siswa.

Dari beberapa metode pembelajaran tersebut di atas, metode pembelajaran dengan penemuan terbimbing digunakan dalam proses pembelajaran (Guided Discovery Learning) karena metode ini lebih sesuai untuk melatih keterampilan berpikir kritis siswa pada tingkat sekolah dasar dan menengah meskipun pada saat ini mulai diterapkan di perguruan tinggi. Bruner (1966, dalam Nur, 2008: 10), penganjur pembelajaran penemuan (Discovery Learning), menyatakan ide tersebut bahwa mengajarkan bahan kajian tidak untuk menghasilkan perpustakaan hidup tetapi lebih ditujukan untuk membuat siswa berfikir. Guru yang menganut tujuan pokok Bruner, yaitu menjadikan siswa mampu berdiri sendiri, harus mendorong siswa untuk mandiri sedini mungkin sejak dari awal masuk sekolah.

Dari beberapa penjelasan di atas, maka dapat dikatakan bahwa metode pembelajaran penemuan (Discovery Learning) efektif untuk dapat mengaktifkan siswa dalam proses pembelajaran. Metode pembelajaran penemuan merupakan metode yang tepat yang dapat membimbing dan memotivasi siswa atau pebelajar untuk mengeksplorasi informasi-informasi dan sejumlah konsep sehingga mengkonstruksi ide-ide baru, mengidentifikasi suatu hubungan baru, dan menciptakan model berpikir dan berperilaku.

Permasalahan utama yang dihadapi guru IPA fisika di SMP YDWP Lab. Unesa yaitu belum adanya perangkat pembelajaran yang dapat dijadikan sebagai contoh atau referensi untuk mengembangkan instrumen terkait dengan materi pembelajaran IPA fisika melalui metode pembelajaran penemuan terbimbing (guided discovery) yang mampu melatihkan kemampuan berpikir kritis siswa. Hal ini didukung oleh hasil penelitian Liliasari \& Redhana (2008) yang menyatakan bahwa perlu adanya program pembelajaran yang mampu membelajarkan siswa dalam hal keterampilan berpikir kritis. Dengan demikian akan memberikan manfaat lain, diantaranya guru dapat: (1) mengetahui gambaran kemampuan berpikir kritis siswa dalam memecahkan masalah; (2) mengemas pembelajaran yang memudahkan siswa belajar; dan (3) menginspirasi guru merancang program pembelajaran yang dapat mendorong siswa berpikir lebih kritis, cermat, dan terampil.

\section{METODE PENELITIAN}

Penelitian ini merupakan jenis penelitian pengembangan perangkat yang dikembangkan dari Model Pengembangan Kemp. Perangkat pembelajaran yang dikembangkan yaitu perangkat pembelajaran IPA SMP pada materi Cahaya. Pada saat pelaksanaan tindakan di lapangan rancangan penelitian yang digunakan adalah One-Group Pretestt - Posttest Design (Prabowo, 2011: 36) dengan rancangan sebagai berikut: 


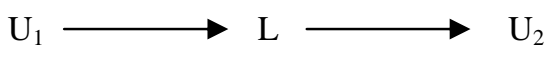

Keterangan:

$\mathrm{U}_{1}=\mathrm{Uji}$ Awal (Pretest)

$\mathrm{L}=$ Perlakuan (penerapan pengembangan perangkat dengan metode pembelajaran Guided Discovery Learning)

$\mathrm{U}_{2}=\mathrm{Uji}$ akhir (Posttest)

Populasi dalam penelitian ini adalah seluruh siswa kelas VIII SMP YDWP Laboratorium Unesa dengan sampel sebanyak 75 siswa kelas VIII.

Tahap awal penelitian ini yaitu mengembangkan perangkat pembelajaran terkait Lembar Kegiatan Siswa (LKS); Buku Siswa; Lembar Penilaian Penguasaan Konsep; Lembar Penilaian Keterampilan Berpikir Kritis; Lembar Pengamatan Proses Pembelajaran, yang meliputi Lembar Pengamatan Keterlaksanaan Pembelajaran; Lembar Pengamatan Aktivitas Siswa dan Lembar Respon Siswa. Perangkat yang telah dikembangkan kemudian divalidasi oleh para pakar pendidikan yang kompeten dibidangnya. Selanjutnya, tahap ke dua perangkat siap diimplementasikan (ujicoba) ke lapangan. Pada tahap ke tiga, hasil pretest dan posttest, dilakukan analisis deskriptif kualitatif dari skor perolehan siswa pada tes keterampilan berpikir kritis siswa dan penguasaan konsep kognitif. Pemberian skor didasarkan pada rubrik penilaian (Rahmawati, 2012).

Selanjutnya, data hasil pretest dan posttest keterampilan berpikir kritis dilakukan analisis deskriptif kualitatif yaitu analisis N-Gain. N-Gain dirumuskan oleh Hake (1999:1) sebagai berikut:

Keterangan:

$$
\%<\mathrm{g}>=\left(\%<\mathrm{S}_{\mathrm{f}}-\mathrm{S}_{\mathrm{i}}>\right) /\left(100-\%<\mathrm{S}_{\mathrm{i}}>\right)
$$

$\langle\mathrm{g}\rangle=$ indeks gain $(\mathrm{N}-$ Gain $) ;\left\langle\mathrm{S}_{\mathrm{i}}\right\rangle=$ perolehan skor pretest; $\left\langle\mathrm{S}_{\mathrm{f}}\right\rangle=$ perolehan skor posttest

Kriteria N-Gain terbagi atas 3 kategori yakni: (1) Pembelajaran dengan "gain-tinggi", jika $\langle\mathrm{g}\rangle \geq 0,7$; (2) pembelajaran dengan "gain-sedang", jika 0,7$\rangle\langle\mathrm{g}\rangle \geq$ 0,3; dan (3) pembelajaran dengan "gain-rendah", jika $<\mathrm{g}><0,3$. Untuk melihat perbandingan signifikan hasil tes keterampilan berpikir kritis pretest dan posttest maka dilakukan t-Test. Demikian halnya dengan tes penguasaan konsep. Untuk memastikan apakah data yang diperoleh dapat dilakukan analisis t-Test, maka terlebih dahulu dilakukan Uji Normalisasi dan Uji Homogenitas data.

\section{HASIL PENELITIAN DAN PEMBAHASAN}

Perangkat RPP yang telah dikembangkan dan divalidasi berada pada skor 3.5-4.5, yang berarti berada pada kategori baik. LKS yang dikembangkan dengan sejumlah komponen juga berada pada kategori baik yaitu 3.5-4.3. Sementara itu, buku siswa yang telah dikembangkan juga berada pada kategori baik untuk digunakan yaitu skor 3.7-4.5. Demikian halnya dengan instrumen tes keterampilan berpikir kritis dan tes penguasaan konsep berada pada kategori baik yaitu 3.03.7 .

Hasil pengamatan keterlaksanaan pembelajaran juga memberikan hasil berada pada kategori baik antara 3.0-4.0. Sementara hasil pengamatan untuk aktivitas siswa dalam KBM menunjukkan skor 3.0-4.0 untuk setiap aspeknya. Hal ini ditunjukkan pada Gambar 1. diagram berikut.

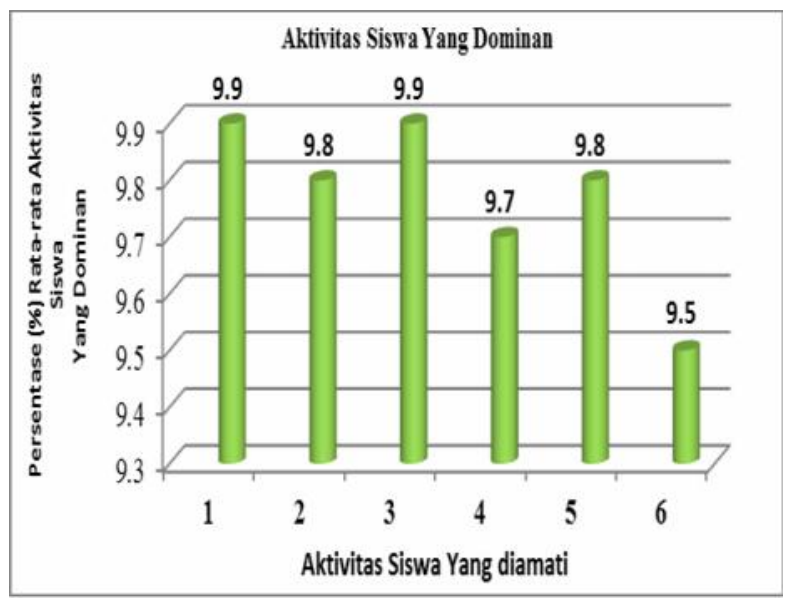

Gambar 1. Aktivitas dominan siswa selama KBM Keterangan:
$1=$ merumuskan hipotesis
$2=$ menuliskan variabel manipulasi
$3=$ menuliskan variabel kontrol
$4=$ menuliskan variabel respon
5 = melakukan percobaan
$6=$ mengumpulkan data

Hasil tes keterampilan berpikir kritis siswa menunjukkan nilai N-Gain rata-rata pada setiap indikator KBK berada pada kategori sedang untuk tiga kelompok siswa. selengkapnya disajikan dalam bentuk diagram batang Gambar 2 berikut.

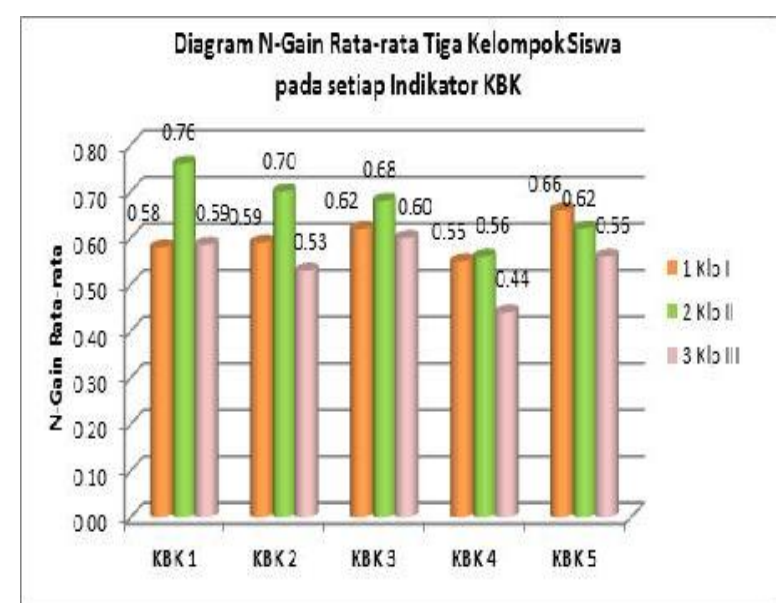

Gambar 2. Diagram N-Gain Rata-rata Keterampilan Berpikir Kritis Siswa pada Tiga Kelompok 
Pada diagram batang Gambar 2. menunjukkan nilai $\mathrm{N}$-Gain rata-rata hasil tes keterampilan berpikir kritis siswa berada pada kategori sedang, yaitu di antara 0.3 dan 0.7 (Hake, 1999). Hasil yang diperoleh terkait keterampilan berpikir kritis siswa adalah nilai N-Gain rata-rata pada masing-masing kelompok masih berada pada kategori sedang, meskipun pada dasarnya bahwa pembelajaran dengan metode penemuan terbimbing harapannya agar mampu melatihkan keterampilan berpikir kritis siswa sampai pada kategori tinggi, tetapi bukan berarti bahwa pembelajaran dengan metode penemuan terbimbing sama sekali tidak memberikan kontribusi dalam melatihkan keterampilan berpikir kritis.

Untuk dapat mengetahui apakah terdapat perbedaan hasil tes keterampilan berpikir kritis siswa sebelum dan sesudah mengikuti pembelajaran dengan metode guided discovery maka dilakukan analisis t-Test dua pihak, $\alpha=5 \%(0.05)$.

Berdasarkan Tabel 1 terlihat nilai rata-rata Pretest adalah 20.59 sementara nilai rata-rata Posttes adalah 71.78. Nilai rata-rata posstest lebih besar dari nilai ratarata pretest. Tabel 1 juga menunjukkan bahwa nilai $\mathrm{t}$ hitung sebesar minus 26.396, signifikansi 0.00 lebih kecil daripada $\alpha$ (0.025) sehingga dapat diambil keputusan menolak H0. Hasil perhitungan t hitung (-26.396) lebih kecil daripada t tabel (1.98). Dengan hasil tersebut dapat disimpulkan bahwa terdapat perbedaan keterampilan berpikir kritis siswa yang signifikan yang dilatih melalui pembelajaran dengan metode penemuan terbimbing.
Berdasarkan analisis N-Gain dan t-Tes, ada beberapa hal yang perlu diperhatikan. Pertama, untuk mampu membuat siswa dapat merumuskan suatu permasalahan terkait dengan materi dalam pembelajaran siswa harus dalam kondisi fokus dan konsentrasi penuh. Namun kenyataannya dalam proses pembelajaran hal yang masih dianggap sulit dilakukan guru adalah memfokuskan perhatian siswa di awal pembelajaran.

Temuan ini diperkuat oleh pernyataan Kuswana (2011: 25) bahwa mengarahkan perhatian dengan mengklarifikasi bahasa pemikiran sebagai kerangka kerja dan taksonomi akan membantu siswa dalam mencapai tujuan belajar. Kedua, proporsi melatihkan kelima indikator berpikir kritis berlangsung tampak tidak merata disebabkan oleh keterbatasan waktu. Di samping itu, dalam proses penemuan konsep dan menyelesaikan suatu masalah terkait materi cermin tidak selalu semua indikator berpikir kritis muncul dalam waktu yang sama atau dalam suatu satu rangkaian proses penemuan tersebut. Artinya bahwa hanya pada waktu-waktu tertentu siswa dilatihkan indikator-indikator berpikir kritis tersebut. Hasil penelitian Hake (1999) mengenai hasil tes pemahaman konseptual pada materi Mekanika Newtonian terkait dengan penerapan metode pembelajaran interaktif dan tradisional. Pada hasil penelitian ini diperoleh bahwa $85 \%$ siswa berada pada $\mathrm{N}$ Gain sedang yaitu 0.48 untuk pembelajaran dengan metode pembelajaran interaktif. Sementara pembelajaran tradisional hampir seluruhnya berada pada N-Gain rendah yaitu 0.23 , dan tidak ada yang berada pada kategori tinggi.

Tabel 1. Data Hasil Pretest dan Posttest Keterampilan Berpikir Kritis Siswa dengan Statistik t-Test

\begin{tabular}{|c|c|c|c|c|c|c|c|c|c|c|}
\hline \multirow[b]{2}{*}{ Jenis Tes } & \multicolumn{2}{|c|}{ Pretest } & \multicolumn{2}{|c|}{ Posttest } & \multirow[b]{2}{*}{$\begin{array}{l}\text { Nilai t } \\
\text { hitung }\end{array}$} & \multirow[b]{2}{*}{$\mathbf{N}$} & \multirow[b]{2}{*}{ Korelasi } & \multirow[b]{2}{*}{ dk } & \multirow[b]{2}{*}{$\begin{array}{c}\text { Nilai } \\
t \\
\text { tabel }\end{array}$} & \multirow[b]{2}{*}{$\begin{array}{l}\text { Sig. } \\
(2- \\
\text { tailed) }\end{array}$} \\
\hline & $\begin{array}{c}\text { Rata- } \\
\text { rata } \\
\left(\overline{x_{1}}\right)\end{array}$ & $\begin{array}{c}\text { Standar } \\
\text { deviasi } \\
\left(\mathrm{s}_{1}\right)\end{array}$ & $\begin{array}{l}\text { Rata- } \\
\text { rata } \\
\left(\overline{x_{2}}\right)\end{array}$ & $\begin{array}{c}\text { Standar } \\
\text { deviasi } \\
\left(\mathbf{s}_{2}\right)\end{array}$ & & & & & & \\
\hline KBK & 20.59 & 11.49 & 71.78 & 13.97 & -26.396 & 75 & 0.141 & 74 & 1.98 & 0.00 \\
\hline $\begin{array}{c}\text { Pemahaman } \\
\text { konsep }\end{array}$ & 18.50 & 5.78 & 83.54 & 7.74 & -65.07 & 75 & 0.220 & 74 & 1.98 & 0.00 \\
\hline
\end{tabular}

Selanjutnya, dari hasil analisis N-Gain dalam penelitian ini menggambarkan bahwa metode pembelajaran penemuan terbimbing mampu melatihkan keterampilan berpikir kritis siswa. Faktor pendukung lain ketercapaian keterampilan berpikir kritis siswa berada pada kategori sedang adalah frekuensi pertemuan pembelajaran yang dilakukan hanya sebanyak tiga kali pertemuan, padahal untuk mampu melatihkan keterampilan berpikir kritis siswa perlu beberapa kali pertemuan dalam pembelajaran bahkan memerlukan waktu yang panjang sehingga memberikan kesempatan kepada siswa untuk senantiasa terlatih dengan pertanyaan-pertanyaan dari guru yang sifatnya menantang siswa untuk mengemukakan gagasannya sendiri. Hal ini sejalan dengan teori Vygotskian (dalam Kuswana, 2011: 25) bahwa pendidik harus mencoba untuk membantu peserta didik terlibat dalam pemikiran tingkat yang lebih tinggi melalui bantuan terstruktur telah semakin diterima dalam dekade ini. 
Hal ini menunjukkan bahwa metode penemuan terbimbing dimana siswa melakukan percobaan untuk menemukan dan memahami konsep-konsep, prinsipprinsip dan fakta dalam pembelajaran IPA yang dipandu dengan LKS, siswa diberi kesempatan untuk mengembangkan gagasan dan keterampilan berpikirnya. Dengan demikian, apabila kegiatan ini senantiasa dilatihkan maka tentunya akan semakin memberi peluang peserta didik untuk berpikir kritis. Pernyataan ini diperkuat oleh hasil penelitian Bindel (1997) terkait dengan pemilihan metode pembelajaran dalam memahamkan hukum kalor jenis pada siswa di Pomona High School yang menyatakan bahwa metode pembelajaran Guided Discovery memberikan kesempatan kepada siswa mengajukan sejumlah rumusan masalah, mempersiapkan, dan merancang eksperimen untuk mencoba menjawab rumusan masalah tersebut, menganalisis data percobaan, kemudian menggunakan analisis data untuk menjawab pertanyaan penelitian yang pastinya berkaitan secara langsung dengan eksperimen. Bindel juga mengungkapkan bahwa metode pembelajaran penemuan terbimbing ini memberikan kesempatan kepada siswa untuk menemukan melalui penggunaan metodelogi sains.

Penelitian ini sejalan dengan hasil penelitian Suryani (2009) menemukan bahwa pembelajaran dengan penemuan terbimbing memiliki dampak positif terhadap pengembangan keterampilan berpikir kritis siswa yang berkaitan dengan pengembangan intelegensi siswa dan mempunyai pengaruh pada peningkatan motivasi belajar siswa. Selain itu juga sesuai dengan pernyataan Nur (2008: 11) melalui metode penemuan siswa belajar memecahkan masalah secara mandiri dan keterampilan berpikir kritis karena mereka harus selalu menganalisis dan menangani informasi.

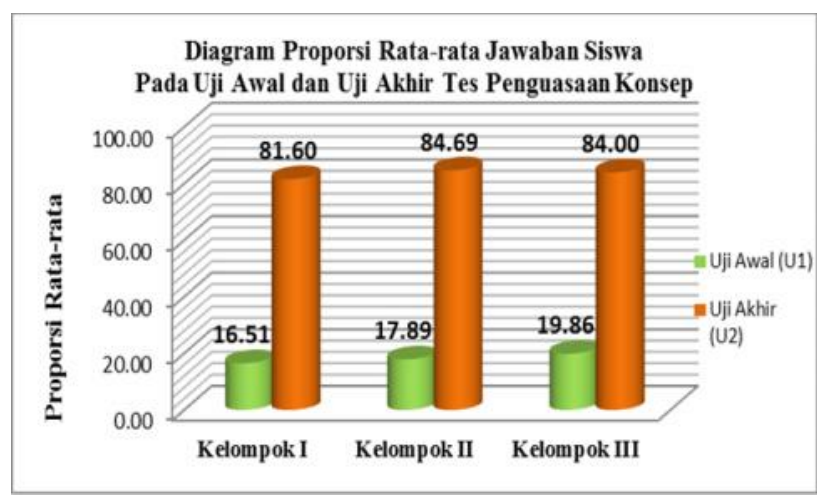

Gambar 3. Diagram Proporsi Rata-rata Jawaban Siswa Pada Uji awal dan Uji akir Tes Penguasaan Konsep

Selanjutnya, pada tes penguasaan konsep pada tiga kelompok menunjukkan bahwa pada uji awal (pretest) proporsi rata-rata jawaban seluruh siswa dari tiga kelompok kurang dari 70 yang artinya tidak tuntas. Sedangkan pada uji akhir (posttest) proporsi rata-rata jawaban siswa pada kelompok I, II, dan III masing- masing adalah 81.60, 84.69, dan 84.00. Nilai ini menunjukkan berada di atas nilai KKM yaitu 70 yang berarti seluruh siswa berada pada kategori tuntas. Ketika ditinjau baik pada ketuntasan individu maupun kelompok maka seluruh siswa pada kelompok I, II, dan III mencapai ketuntasan. Secara jelas dapat ditunjukkan pada Gambar 3.

Berdasarkan Tabel 1 terlihat nilai rata-rata Pretest adalah 18.50 sementara nilai rata-rata Posttes adalah 83.54. Nilai rata-rata posstest lebih besar dari nilai ratarata pretest. Tabel 1 juga menunjukkan bahwa nilai $\mathrm{t}$ hitung sebesar minus 65.07, signifikansi 0.00 lebih kecil daripada $\alpha(0.025)$ sehingga dapat diambil keputusan menolak H0. Hasil perhitungan t hitung (-65.07) lebih kecil daripada $t$ tabel (1.98). Dengan hasil tersebut dapat disimpulkan bahwa terdapat perbedaan hasil tes belajar siswa yang signifikan setelah diajar melalui pembelajaran metode penemuan terbimbing. Sementara hasil respon siswa terhadap pembelajaran dengan metode penemuan terbimbing terhadap setiap aspek menunjukkan respon yang positif.

\section{PENUTUP}

\section{Simpulan}

Berdasarkan hasil penelitian ini dapat disimpulkan bahwa pengembangan perangkat pembelajaran dengan metode penemuan terbimbing cenderung dapat mengembangkan keterampilan berpikir kritis siswa dan penguasaan konsep siswa. Selain itu ditemukan bahwa sebagian besar siswa menunjukkan sikap positif terhadap pembelajaran IPA fisika dengan metode penemuan terbimbing.

\section{Saran}

Untuk mendukung proses pelaksanaan melatihkan keterampilan berpikir kritis siswa di sekolah tingkat SMP, khususnya SMP Laboratorium Universitas Negeri Surabaya pada mata pelajaran IPA fisika terkait sub materi cermin, guru-guru dapat menggunakan perangkat yang telah dikembangkan ini.

\section{DAFTAR PUSTAKA}

Bindel, T.H and Fochi, J.C. 1997. "Guided Discovery: Law of Specific Heats". Journal of Chemical Education. Vol.74. No.8, August 2007. pp. 955957.

Ennis, R. H. 1996. Critical Thinking. United State of America: Prentice- Hall.

Facione, P.A. 2010. Critical Thinking: What It Is and Why It Counts. Millbrae: Measured Reasons and The California Academic Press.

Hake, R.R. 1999. American Educational Research Association's Division D, Measurement and Research Methodology: Analyzing Change/Gain Scores. USA: Woodland Hills. 
Hergenhahn, B.R \& Olson, M. H. 2009. Theories of Learning The Seventh Edition. Jakarta: Kencana Prenada Media Group.

Ibrahim, M. 2005. Asesmen Berkelanjutan (Konsep Dasar, tahapan pengembangan, dan contoh). Surabaya: Unesa University Press.

Jalal, F. 2012. "Pengambilan Kebijakan Tentang Guru Berdasarkan Bukti (Evidence Based Decision Making)". Makalah Utama Simposium Nasional Hasil Penelitian Tentang Guru.

Kuswana, W. S. 2011. Taksonomi Berpikir. Bandung: PT. Remaja Rosdakarya.

Liliasari \& Redhana, I W. 2008. "Program Pembelajaran Keterampilan Berpikir Kritis Pada Topik Laju Reaksi Untuk Siswa SMA”. Jurnal Forum Kependidikan. Vol. 27. No. 2, Maret 2008.

Maulana. 2008. "Alternatif Pembelajaran Matematika dengan Pendekatan Metakognitif untuk Meningkatkan Kemampuan Berpikir Kritis Mahasiswa PGSD”. Jurnal Pendidikan Dasar. Vol. 10. Hal. 36-46.

Morgan, W. R. 1995. "Critical Thinking What does That Mean? Journal of College and Science Teaching". 24 (5). Pp. 336-390.

Nur, M \& Wikandari, P.R. 2008. Pengajaran Berpusat Kepada Siswa dan Pendekatan Konstruktivis dalam Pengajaran. Surabaya: Pusat Sains dan Pendidikan Matematika Sekolah Universitas Negeri Surabaya.
Nurmaliah, C. 2009. "Keterampilan Berpikir Kritis, Metakognisi, dan Penguasaan konsep Biologi Siswa SMP Negeri di Kota Malang”. Disertasi Doktor, Universitas Negeri Malang.

Rahmawati, Widodo, W, dan Prabowo. 2012. " Melatih Keterampilan Berpikir Kritis Siswa SMP Melalui Metode Pembelajaran Penemuan Terbimbing (Guided Discovery) Pada Mata Pelajaran IPA". Jurnal Inovasi 2012. Vol. 09. Hal. 58-70.

Rochaminah, S. 2008. "Penggunaan Metode Penemuan untuk Meningkatkan Kemampuan Berpikir Kritis Matematis Mahasiswa Keguruan". Artikel Penelitian.

http://www.puslitjaknov.org/data/file/2008/makalah _peserta/07_Sutji\%20Rochaminah_Penggunaan\%2 0Metode\%20untuk\%meningkatkan\%20kemampuan .pdf. Diakses tanggal 6 Januari 2011.

Simposium Nasional. 2012. Makalah Utama dan Prosiding Simposium Nasional Hasil Penelitian Tentang Guru. Surabaya: Universitas Negeri Surabaya.

Suryani, N.D. 2009. "Pengembangan Keterampilan Berpikir Kritis Siswa pada Pembelajaran Fisika untuk Materi Pokok Kalor Melalui Model Pembelajaran Penemuan Terbimbing (Guided Discovery) di Kelas X-3 SMA Negeri 1 Gedangan. Jurnal Pendidikan Delta Widya, Jilid 2. No.2 Tahun 2009. 